cxample, of Wickerhnm in 1951) remain subjects of debate. Likewise it will surprise many to have it rccalled that the recognition of the alternation of generations in yeasts goes back only to 1935 , that the concept of "sexual" mating types followed little more than twenty years ago and that the comparatively littlo that is known of yeast genetics is even more recent.

With its wealth of newly co-ordinated information the fow quite unimportant crrors can be disregarded. They are more than compensated by a number of appendices including a useful listing of genera and diagnoses. It is slightly rogrottable that no original papers are cited though a list of probably all the major monographs of the field will to a large extent meet this need indirectly.

A. H. CooK

\section{LICHENS FOR STUDENTS}

\section{The Biology of Lichens}

(Contomporary Biology.) By Mason E. Hale, Jun. Pp. viii +176 . (London: Edward Arnold (Publishers), Ltd., 1967.) 42s. net boards; $21 s$. net paper.

'THIs is a good book. It is an eminently successful account of lichens for the student. Although it docs not aim to be an encyclopaedic work of scholarship, its coverage of the literature is remarkably good, and the clarity with which it is written is outstanding. Its scope is wide: it deals with the fundamental aspects of the morphology, reproduction, ecology and classification of lichens, and lays particular omphasis on the subjects of symbiosis, physiology and chemical taxonomy.

The most valuable quality of this book is the excellent way it deals with those aspects of the biology of lichens which are almost always misunderstood by students. The wealth of fascinating problems concerning reproduction of lichons is presented very clearly. In discussing concepts of symbiosis, Dr Hale gives vory lucid explanations of what various authors have had in mind, but stresses our continuing ignorance of tho nature of the lichen symbiosis. A scction on the physiological relationships of the symbionts begins with the excellent statement: "Dialectic arguments about symbiosis aro no substitute for exporimental proof". At first glanee, the chapter on the chemistry of lichens may seem to require more knowledge of organic chemistry than should bo expected of a biology student. It is written, however, with suporb clarity, and is an essential precursor to the succeeding chapter on chomical taxonomy, the best in the whole book.

As in any book, there are some small errors. I am embarrassed to be credited on page 61 with a comparison of rates of ${ }^{14} \mathrm{CO}_{2}$ fixation between Trebouxia and Chlorella: this work was actually carriod out by Cecil Fox. Drew's studies of Pelligera polydactyla mentioned on page 59 showed that glucose is converted to mannitol in the algal layer, not tho medulla, during photosynthesis. Somo of the plates are poor, and $1 D, 1 E$ and $6 B$ look more like objocts from outer space than algal colls and soredia. In the next edition, the printers really must try to make the fifteen labels on plate twelve more logible.

$I$ found the chapter on eeology the least stimulating. T am most sorry that Ried's (1963) work on zonation of lichens was omitted, beenuse I believe this to be the best and most thorough pieco of physiological ecology carried out on lichens, and I feel it deserves a wholo scetion in a book of this kind. In dealing with atmospheric pollution, it is a pity to find no mention of Gilbert's work on the Newcastle area, because this provides better direct $\theta v i$ dence than most other eeological studies of the effects of sulphur dioxide on licheu distrikution.

But despito such eriticisms, which are the sort that one specialist can always make about another, this book is to bo highly reommonded.

\section{USING THE LIGHT}

Primary Productivity in Aquatic Environments

Edited by Charles R. Goldman. (Procecdings of an I.B.P. PF Symposium, Pallanza, Italy, April 26-May 1, 1965.) Pp. 464. (Berkeley and Los Angeles: University of California Press; London: Cambridge University Press, 1966.) $\$ 7$; 56s. net.

This volume is neither a recipe-book methodology nor a simple collection of rescarch papers. Most of the contributions have a strong emphasis on the methods employed in production research and their potential sources of error, or on their underlying philosophy. Prosumably the intention is to give cxamples of how freshwater productivity data can bo obtained so that participants in the International Biological Programme can follow, modify or dovelop these examples.

Three examples from the twonty-seven contributions indicate the sort of topies and their treatment. Jorgensen and Stecmann-Nielsen discuss the ways in which planktonic algae adapt themselves to factors such as temperature and light intensity, primarily by varying the concentrations of photosynthetic pigments and various enzymes. This is obviously important to anyone wishing to extrapolate from experimental data to the field situation.

Fogg and Watt discuss the release of glycollic acid as an extracellular product of photosynthesis by phytoplankton. The amounts released can be quite significant, more so in oligotrophic than eutrophic waters, and especially in surface waters at high light intensitios. This is a potential source of error in the use of the radiocarbon method for estimating photosynthesis.

Margalef contributes a stimulating paper on the relationship between primary production and community strueture in phytoplankton communities. This emphasizes the importance of (and therefore the need to measure) community structure either as some index of species composition, or as a simple pigment ratio.

Other important topics discussed include mechanisms of photosynthesis, the factors limiting primary production in natural phytoplankton populations, the importance of planktonic bacteria, production by higher plants in aquatic environments, the value of standing crop data in estimating primary production and the comparison of seasonal and spatial variation in phytoplankton populations and production rates in a temperate and a tropical lake.

Fach paper has an abstract and a reference list and the whole volume is well edited and produced. The instigation and speedy publication of well-designed conferences will clearly be an important function of $\mathrm{IBP}$ and it has got off to a good start.

P. J. NEWBOUID

\section{POTTED MAMMALS}

\section{Recent Mammals of the World}

A Synopsis of Families. Edited by Sydney Anderson and J. Knox Jones, jun. Pp. viii + 453. (New York : The Ronald P'ress Company, 1967.) \$12.50.

THIs book is the culmination of a series of check lists or bonch books compiled for their own usc by a succossion of graduate students and staff members of the University of Kansas. It began as long ago as 1953 when the contributors prepared an outline of each order and family of living mammals; this proved so useful that it was improved and extended in 1959, and then further revised and expanded with the assistance of mammalogists in other institutions to form the present volume. $\Lambda \mathrm{s}$ the editors say, the final rosult reflects a commendable degree of teamwork on the part of all contributors in writing to agreed standards of objectivity and concisencss. 